\title{
The FTC Proposed Regulation of Prescription Drug Price Disclosure by Retail Pharmacists
}

The Federal Trade Commission Improvement Act of $1975^{1}$ confirmed the FTC's authority to issue trade regulation rules that "define with specificity acts or practices which are unfair or deceptive."' The Act further provides that such rules "may include requirements prescribed for the purpose of preventing such acts or practices." 3 Premised on this authority, the FTC has proposed three trade regulation rules ${ }^{4}$ designed to promote the disclosure ${ }^{5}$ of pre-

15 U.S.C.A. \$ 57(a) (Supp. 1975).

${ }^{2}$ Id.

3 Id.

- Only the first two of these rules have been officially proposed. 40 Fed. Reg. 24031 (June 4,1975 ). Rulemaking proceedings are currently in progress and are expected to be completed by June, 1976. BNA-ATRR, No. 716, at A-3 (June 3, 1975). The proposed rules are based on a lengthy study of the issue by the staff of the FTC. The data, analysis and conclusions of the staff are embodied in a volume entitled Prescription Drug Price Disclosure: Staff Report to the Federal Trade Commission (Jan. 28, 1975) [hereinafter cited as StafF REPORT]. Although the FTC has relied on the research of the staff in its decision to publish the proposed rules, should be recognized that the Commission has not officially adopted any findings or conclusions of the staff. All of the findings in the rulemaking proceeding currently in progress will be based solely on the rulemaking record; the Staff Report will be included as a part of this official record.

3 Twenty-two states currently regulate directly the disclosure of prescription drug prices. Ten of these states restrict disclosure by statute. See Alaska Stat. $\$ 08.80 .420$ (b) (Supp. 1972); Ariz. Rev. Stat. Ann. § 32-932(B)(3) (Supp. 1972-73); Cal. Bus. \& Prof. Code § 651.3 (West Supp. 1972); Conn. Gen. Stat. Ann. § 20-175A (Supp. 1975); Fla. Stat. Ann. § 465.23 (Supp. 1973); La. Rev. Stat. AnN. § 39:1225(11) (1964); N.J. Stat. AnN. § 45:14-12(c) (Supp. 1972-73); N.D. Cent. Code § 43-15-10(1)(b) (1960); OkLA. Stat. AnN. tit. 59, § 736.1 (1971); TEx. Rev. Civ. Stat. ANN. art. 4542(a), \& 17(d)(3) (1960). The remaining twelve states have relied on state pharmacy board regulations (Alabama, Georgia, Indiana, Iowa, Kansas, Maine, Minnesota, Mississippi, New York, Rhode Island, South Dakota, and West Virginia). As of November, 1975, however, three of the states (California, Kansas, and Texas) were contemplating the total or partial repeal of disclosure prohibitions and/or the enactment of mandatory disclosure requirements. Moreover, two states (Connecticut and Maine) have recently removed most, though not all, state restraints. Telephone interview with Matthew Daynard, FTC Staff Attorney, November 25, 1975, Washington, D.C.

Seven additional states restrict disclosure indirectly. Two of these (Colorado and Ohio) require that all advertisements for prescription drugs include extensive medical information concerning ingredients and contraindications. The remaining five states (Hawaii, Illinois, Kentucky, Missouri, and Pennsylvania) ban the advertising of "controlled substances."

Although no state prohibits either "in-store verbal" disclosure or telephone disclosure, only seven states (California, Hawaii, Minnesota, Nevada, New York, South Dakota, and Washington) require either or both. And three of these states (Hawaii, Minnesota, and New York) do not require such disclosure unless the inquirer possesses a valid prescription. 
scription drug price information by retail pharmacists. The current limits on the availability of this information have been attributed primarily to state statutes and state pharmacy board regulations that prohibit or restrict disclosure and to private restraints on disclosure by pharmaceutical associations. ${ }^{B}$ According to the FTC these restraints have resulted in substantial and unjustifiable economic harm to consumers. ${ }^{7}$ The proposed rules purport to eliminate this economic harm on the grounds that the nondisclosure of drug prices constitutes an "unfair"-as distinguished from "deceptive"8-act or practice. The proposals represent the most ambitious recent attempt by the Commission to test its authority and enlarge its role in the field of consumer protection. ${ }^{9}$

Seven states require "in-store posting" of prices (California, Michigan, Minnesota, New Hampshire, New York, Texas, and Vermont).

Only fifteen states have no statutes or regulations restricting disclosure in any form (Delaware, District of Columbia, Idaho, Montana, Nevada, New Hampshire, North Carolina, Oregon, South Carolina, Tennessee, Utah, Vermont, Washington, Wisconsin, and Wyoming).

- The private restraints derive basically from codes of ethics adopted by state and local pharmaceutical associations at the encouragement of the two major national private pharmaceutical associations-the American Pharmaceutical Association (APA) and the National Association of Retail Druggists. The codes are generally modeled after the following APA provisions:

Section 7: A pharmacist should not agree to practice under terms or conditions which can interfere with or impair the proper exercise of his professional judgment and skill, or which tend to cause a deterioration of the quality of his service or which require him to consent to unethical conduct.

Section 8: A pharmacist should not solicit professional practice by means of advertising or by methods inconsistent with his opportunity to advance his professional reputation through service to patients and to society.

Code of Ethics of the American Pharmaceutical Association, adopted September, 1969. See also Advisory Opinion 2-70, Report of the Judicial Board to the APA House of Delegates, April 12,1970 , at 3 . Codes of ethics are in effect and actively enforced in eleven of the fifteen states having no statutory or regulatory restraints on disclosure. Nineteen of the thirty-six states which have adopted codes of ethics in restraint of disclosure have also subscribed to the APA Code.

The FTC staff has estimated that the two proposed rules alone will ultimately save drug buyers more than $\$ 200$ million on the nearly $\$ 7$ billion a year that are spent on prescription drugs. See Two Pharmacist Groups Are Sued by U.S. Over 'Codes of Ethics' Barring Drug Ads, Wall St. J., Nov. 25, 1975, at 2, col. 3 [hereinafter cited as Two Pharmacist Groups].

8 "Deceptive" may fairly be understood as the major subcategory of "unfair," but not the exhaustive definition of that term. STAFF REPoRT, supra note 4, at 293; see Sperry \& Hutchison v. FTC, 405 U.S. 233 (1972); FTC v. R.F. Keppel \& Bros., Inc., 291 U.S. 304 (1934). The FTC has only recently indicated an interest in prosecuting acts or practices which are "unfair" without also being "deceptive." But see Bristol-Myers Co., 46 F.T.C. 162 (1949).

- The FTC has recently announced plans to extend its efforts with respect to the disclosure of price information to include other professions as well. See, e.g., FTC Charges Illegality in Curb on Doctors' Ads, N.Y. Times, Dec. 23, 1975, at 24, col. 2; FTC Plans to Study Realty, Veterinary, Repair Industries, Wall St. J., Dec. 29, 1975, at 2, col. 2. The Drug Price Rules thus apparently represent the beginning of a major effort against the nondisclosure of prices among the professions. The success of the Drug Price Rules will undoubtedly influence the 
The substantive content of the proposed rules ${ }^{10}$ can be simply stated. Rule I makes unlawful any private attempt to restrain pharmacists from disclosing prices. Rule II, unlike Rule I, is specifically designed to preempt state laws rather than merely prohibit private restraints. This rule is addressed directly to pharmacists: it prohibits the failure of any pharmacist to disclose prices when such failure is "because of or in connection with"11 any state law or any private restraint. Rule III, as yet unformulated but tentatively proposed by the FTC staff, would affirmatively require pharmacists to disclose prices by certain specified methods, ${ }^{12}$ even when the failure to disclose is not due to the presence of private or governmental restraints.

This comment will analyze the FTC's proposed rules to determine whether the nondisclosure of drug prices may properly be regarded as an unfair or deceptive act or practice which the FTC is

course of this effort and the extent to which trade regulation rules will be used to achieve the goal of price disclosure.

10 The full text of the most pertinent provisions is as follows:

Rule I: It is an unfair act or practice for any person, partnership, or corporation directly or indirectly to prohibit, hinder, or restrict, or attempt to prohibit, hinder, or restrict, the disclosure by any retail seller of accurate price information regarding prescription drugs, whether such disclosure is made by means of advertisements in print media, broadcast media, or in any other way.

Rule II: (a) It is an unfair act or practice for any retail seller to fail to disclose adequate price information regarding prescription drugs to potential purchasers.

(b) Adequate price information is not disclosed and the requirements of this Rule are violated if the retail seller:

(1) changes, restricts, burdens, makes or fails to make any disclosure of accurate price information by print media, broadcast media, telephone, leaflets, mailings, or in any other way, because of or in connection with any law, rule, regulation or code of conduct of any non-federal legislative, executive, regulatory or licensing entity or any other entity or person whatsoever, including but not limited to professional associations.

Declaration of Commission Intent:

(a) It is the purpose of these Rules, subject only to the requirements of federal statutes and regulations, to allow disclosure of accurate prescription drug price information by retail sellers to prospective purchasers and to eliminate restraints, burdens or controls imposed by non-federal law and by private, state and local governmental action on such disclosure by any means of communication, including but not limited to advertising (other than exempt price disclosure requirements). It is the intent of the Commission that these Rules shall preempt all non-federal laws, ordinances or regulations that are repugnant to these Rules, that would in any way frustrate the purpose of these Rules, that would in any way prevent or burden any disclosures of accurate prescription drug price information by retail sellers to potential purchasers . . . .

40 Fed. Reg. 24031 (June 4, 1975).

" "The purpose of this rule is to create a duty on the part of the [pharmacist] not to be influenced by [state laws or private restraints] in making decisions on whether to disclose." StafF REPORT, supra note 4, at 204.

${ }_{12}$ The methods presently under consideration include: (1) disclosure by telephone, (2) disclosure by in-store catalogue, and (3) disclosure by in-store posting. Id. at 205-06. 
authorized ${ }^{13}$ to prohibit by requiring disclosure ${ }^{14}$ and, if so, whether the FTC can displace state disclosure laws pursuant to the Federal Trade Commission Act. ${ }^{15}$ The comment concludes that the FTC can present a persuasive case for requiring the disclosure of drug prices based on a finding of unfairness apart from deception. The comment also concludes, however, that the doctrine of Parker $v$. Brown will severely limit the ability of the mandatory disclosure requirements contained in Rules II and III to preempt state laws prohibiting drug price disclosure.

\section{The Nondisclosure of Prescription Drug Prices and THE Validity of Mandatory Disclosure Rules}

\section{A. The Doctrine of Unfairness}

The Wheeler-Lea Amendments ${ }^{16}$ to the original Federal Trade Commission Act ${ }^{17}$ extended FTC jurisdiction to include "unfair or deceptive acts or practices" as well as "unfair methods of competition." The Amendments were expressly directed against practices injurious to consumers, ${ }^{18}$ regardless of the effect of such practices on competition. Thus the FTC's claim that the nondisclosure of drug prices is unlawful need not be supported by a showing that nondisclosure is "anticompetitive" in the classic antitrust sense of that term. ${ }^{19}$ As the Supreme Court stated in Sperry \& Hutchinson $v$.

${ }^{13}$ Substantive rules which an administrative agency issues pursuant to a legislative grant of power are valid if they are: (1) constitutional, (2) issued in accordance with proper rulemaking procedure, and (3) within the granted power. $1 \mathrm{~K}$. Davis, ADMinistrative LAW TrEatise $\S 5.03$, at 299 (1958). Since the first two criteria are not at issue, this comment focuses exclusively on the third.

14 Rule I, unlike Rules II and III, involves no requirement of disclosure. However, like Rules II and III its validity depends on whether or not the nondisclosure of drug prices can be regarded as an "unfair or deceptive act or practice."

is 15 U.S.C. $\$ \S 41-58$ (1970); 15 U.S.C.A. $\$ 57$ (a) (Supp. 1975). A third issue-the scope of FTC jurisdiction over retail pharmacists-is uncontroversial and therefore will not be examined. FTC jurisdiction extends to all acts or practices "in or affecting" commerce. Federal Trade Commission Improvement Act, 15 U.S.C.A. \& 57a(a) (Supp. 1975). For decisions affirming that the retailing of prescription drugs is "in commerce," and relying on the "flow of commerce" rationale, see United States v. Sullivan, 333 U.S. 633 (1948), and Northern Cal. Pharmaceutical Ass'n v. United States, 306 F.2d 379 (9th Cir.), cert. denied, 371 U.S. 862 (1962). Since a majority of the prescription drugs sold locally in this country are manufactured out-of-state, FTC jurisdiction extends to most retail pharmacists throughout the country.

i Pub. L. No. 447, 52 Stat. 111 (1938).

1738 Stat. 717 (1914).

18 H.R. Rep. No. 1613, 75th Cong., 1st Sess. 3 (1937).

10 Although in the past neither the FTC nor the Department of Justice has attempted to use antitrust law to eliminate restraints on the disclosure of price information, the Department of Justice filed its first antitrust suit against drug-price disclosure restraints on 
$F T C$, ${ }^{20}$ "the FTC does not arrogate excessive power to itself if, in measuring a practice against the elusive, but congressionally mandated standard of fairness, it, like a court of equity, considers public values beyond simply those enshrined in the letter or encompassed in the spirit of the antitrust laws." 21

According to the FTC, the nondisclosure of drug prices is "unfair" because "its economic and social utility is substantially less than its . . . disutility."22 Although this broad definition arguably conforms to the even broader Sperry language, the actual legal meaning of "unfair" remains purposefully indeterminate. ${ }^{23}$ Despite the fact that the definition of unfairness has been committed by Congress to FTC discretion, the Supreme Court has on one occasion dealt with this definitional issue.

In Sperry, the Court referred ${ }^{24}-$ seemingly with approval-to three factors that the FTC had previously identified ${ }^{25}$ as relevant in determining whether a practice that is neither in violation of traditional antitrust law nor deceptive may nevertheless be regarded as unfair: "(a) whether the practice, without necessarily having been

November 24,1975 . The suit is directed only against private pharmaceutical associations and, unlike the proposed FTC rules, does not reach state statutes or state pharmacy board regulations. Two Pharmacist Groups, supra note 7, at 2.

205 U.S. 233 (1972).

21 Id. at 244.

22 Stafs REPoRT, supra note 4, at 298. The FTC has submitted a second, supplemental allegation to support its characterization of nondisclosure as "unfair": "[]]t [nondisclosure] offends public policy, being basically contrary to clear national policy and not vital to achieve important state policy goals." Id. In formulating this allegation the FTC was obviously anticipating, and seeking to avert, the unfavorable implications of Parker $v$. Brown for the preemptive power of Rules II and III, discussed infra at text accompanying notes 77-123. Yet in so doing the FTC presupposes the very proposition that Parker militates against, that the FTC, as a federal agency, is empowered to assess the wisdom of state laws.

${ }^{23}$ In committing the definition of unfairness to the discretion of the FTC, the Senate Report on the original Federal Trade Commission Act stated: "The Committee gave careful consideration to the question as to whether it would attempt to define the many and variable unfair practices which prevail in commerce and to forbid their continuance or whether it would, by a general declaration condemning unfair practices, leave it to the Commission to determine what practices were unfair. It concluded that the latter course would be better . . . S. Rep. No. 597, 63d Cong., 2d Sess. 13 (1914). See also Section 5 of the FTCAUnfairness to Consumers, 1972 WIS. L. Rev. 1071; Hearings on S. 3744 Before the House Comm. on Interstate and Foreign Commerce, 74th Cong., 2d Sess. 14 (1936) (Wheeler-Lea Amendments).

The status of nondisclosure as an "unfair act or practice" is determined exclusively by whether or not it is "unfair." The argument that nondisclosure is not an "act or practice," since it constitutes mere inaction and is therefore beyond the scope of the Federal Trade Commission Act cannot be supported.

24 U.S. at $244-45$ n.5.

${ }^{25}$ Statement of Basis and Purpose of Trade Regulation Rule 408, 29 Fed. Reg. 8325, 8355 (1964) (Trade Regulation Rule for the prevention of unfair or deceptive advertising and labelling of cigarettes). 
previously considered unlawful, offends public policy as it has been established by statutes, the common law, or otherwise; (b) whether it is immoral, unethical, oppressive or unscrupulous; (c) whether it causes a substantial injury to consumers (or competitors or other businessmen)." ${ }_{26}$ Of these factors, only the first and third are claimed by the FTC to be satisfied by the nondisclosure of drug prices. ${ }^{27}$ As for the second factor, the FTC has not claimed, and probably could not readily demonstrate, that nondisclosure is "immoral, unethical, oppressive or unscrupulous." ${ }^{28}$ Since the FTC does not contend that nondisclosure is "immoral, unethical, oppressive or unscrupulous," it is necessary to determine whether the three factors mentioned in Sperry must be satisfied conjunctively in order to make a showing of unfairness. ${ }^{29}$

The Sperry Court addressed this issue in response to an argument by the defendant that the FTC had stated, in a later portion of the same statement quoted above, ${ }^{30}$ that the mere showing of substantial injury to consumers was insufficient without a concurrent showing of the first and second factors. The FTC had actually asserted that " $[t]$ he wide variety of decisions interpreting the elusive concept of unfairness at least makes clear that a method of selling violates [the Federal Trade Commission Act] if it is exploitive or inequitable and if, in addition to being morally objectionable, it is seriously detrimental to consumers . . . ." 31

The Sperry Court was unsympathetic to the defendant's interpretation of the FTC statement and indicated that the words "at least" admit the possibility that "substantial injury" alone is sufficient to prove unfairness. ${ }^{32}$ Thus the Court, in rebutting the defendant's argument, might plausibly be said to have recognized that

${ }^{28}$ Id.

${ }^{27}$ STAFF REport, supra note 4, at 298.

${ }^{28}$ As applied to the trade practice of drug-price nondisclosure, the second factor would seem to require a showing of unscrupulous intention on the part of nondisclosing retail pharmacists. Such a showing would be considerably burdensome and difficult to determine factually. Furthermore, a showing of requirement (b) would be particularly unlikely in the case of Rule II, which by definition proscribes as unfair only those instances of nondisclosure resulting from deference to state law or submission to private restraints-not autonomous unscrupulous intentions. Cf. Comment, Psychological Advertising: A New Area of FTC Regulation, 1972 Wis. L. REv. 1097, 1108.

${ }^{20}$ Recognition of Sperry in the legislative history of the FTC Improvement Act was confined to a brief statement submitted before a House subcommittee by Sears, Roebuck \& Co. Hearings on H.R. 20 and H.R. 5021 Before the Subcomm. on Commerce and Finance of the House Comm. on Interstate and Foreign Commerce, 93d Cong., 1st Sess., ser. 93-17, at 346 (1973).

so See note 25 supra.

31 Statement of Basis and Purpose, supra note 25 (emphasis added).

32405 U.S. 233, 245 (1972). 
the FTC had not committed itself to the view that all three requirements discussed in Sperry must be met. Unfortunately the Court in Sperry did not analyze this issue further and thus left open the question whether "substantial injury" alone satisfies the test for unfairness. The Court may well have thought that an explicit, formulaic articulation of the criteria for unfairness was unnecessary to its decision and inconsistent with the legislative intent regarding the concept..$^{33}$ In addition, the Court's silence on this question can well be interpreted as a willingness to afford the FTC the traditional judicial respect for an administrative agency's interpretation of its own statute. . $^{34}$

The likelihood of judicial acceptance of a characterization of nondisclosure of drug prices as an unfair act or practice cannot be determined on the basis of existing judicial precedents. Even if, as the Sperry Court came close to implying, the substantial injury requirement is sufficient to establish unfairness, the problem remains that substantial injury is itself an inexact concept. In this situation of uncertainty, the standard of review which a reviewing court applies to the FTC determination assumes critical importance.

While the articulation of a definition of unfairness is a matter committed by Congress to the FTC's discretion, ${ }^{35}$ it is unclear what weight a reviewing court will grant the FTC's exercise of such discretion. To the extent that the FTC's expertise is respected, or that "substantial injury" is viewed as a question of fact, a court will limit its review to the "reasonable basis" test. ${ }^{38}$ Given the controversial nature of the factual questions involved and the conspicuous thoroughness of the FTC's factual investigation, ${ }^{37}$ the FTC can be expected to meet the reasonable basis test. To the extent that unfairness is considered a question of law, a reviewing court will substitute its judgment for that of the FTC. A court would most likely uphold

${ }^{33}$ See note 23 supra.

${ }^{34}$ FTC v. Brown Shoe Co., 384 U.S. 316 (1966); cf. Note, Unfairness Without Deception: Recent Positions of the Federal Trade Commission, 5 Loyola U.L.J. 537, 546 (1974).

ss See note 23 supra.

34 K. Davis, Administrative Law Treatise $\$ 30.14$, at 268 (1958). The most decisive articulated factor that guides the exercise of judicial discretion in choosing between substitution of judgment and use of the reasonable basis test is the comparative qualifications of court and agency to decide the particular issue. Many "mixed" issues of law and fact, however, involve neither judicial nor administrative expertise as a special factor. Id. The issue of "unfairness" is exemplary.

${ }^{37}$ See STAFF REPORT, supra note 4, at 321-472. The purely factual determination involved in ascertaining "unfairness" is beyond the scope of this comment. See generally Benham, The Effect of Advertising on the Price of Eyeglasses, $15 \mathrm{~J}$. Law \& Econ. 337 (1972); Stigler, The Economics of Information, 7 J. PoL. EcoN. 213 (1961). 
the FTC in this situation as well. The few decisions that have dealt with the nondisclosure of drug price information, in the context of suits challenging the constitutionality of state disclosure prohibitions, have been predominantly consistent with the FTC position. ${ }^{38}$

\section{B. The Disclosure Requirement}

The FTC has broad discretion to fashion remedies for violations of the Federal Trade Commission Act. ${ }^{39}$ If the nondisclosure of prescription drug prices can be characterized as an unfair act or practice, the FTC should be able to order any remedy that bears "a reasonable relationship to the unlawful practice."40

In recent years the FTC has frequently ordered, with judicial approval, the affirmative disclosure of information about retail products. But generally it has done so only by either of two methods: (1) "affirmative disclosure," 41 whereby the party is prohibited from advertising in the future unless such future advertisements contain a self-derogatory disclosure as specified by the FTC; and (2) "corrective advertising," 42 whereby the party is required to disclose

33 See, e.g., Virginia Citizens Consumers Council, Inc. v. State Bd. of Pharmacy, 373 F. Supp. 683 (E.D. Va. 1974), prob. juris. noted, 420 U.S. 971 (1975); Florida Bd. of Pharmacy v. Webb's City, Inc., 219 So. 2d 681 (Fla. 1969); Maryland Bd. of Pharmacy v. Sav-A-Lot, Inc., 270 Md. 103, 311 A.2d 242 (1973); Oregon Newspaper Publishers Ass'n v. Peterson, 244 Ore. 116, 415 P.2d 21 (1966). Contra, Patterson Drug Co. v. Kingery, 305 F. Supp. 821 (W.D. Va. 1969); Supermarkets Gen. Corp. v. Sills, 93 N.J. Super. 326, 225 A.2d 728 (Ch. 1966).

39 "The Commission is the expert body to determine what remedy is necessary to eliminate the unfair or deceptive trade practices which have been disclosed. It has wide latitude for judgment . . . J"Jacob Siegel Co. v. FTC, 327 U.S. 608, 612-13 (1946). See also Arthur Murray Studio of Wash., Inc. v. FTC; 458 F.2d 622 (5th Cir. 1972); Tashof v. FTC, 437 F.2d 707 (D.C. Cir. 1970); Consumers Products of America, Inc. v. FTC, 400 F.2d 930 (3d Cir. 1968), cert. denied, 393 U.S. 1088 (1969). Judicial discussions of the issue of remedy are limited to the context of cease and desist orders fashioned under section 5(b) of the Federal Trade Commission Act or section 11(b) of the Clayton Act, but no principled reason exists to doubt their applicability where the remedy takes the form of a trade regulation rule. See 120 CoNG. REC. 12059-60 (daily ed. Dec. 16, 1974).

40 Jacob Siegel Co. v. FTC, 327 U.S. 608, 612-13 (1946).

"See, e.g., Tashof v. FTC, 437 F.2d 707 (D.C. Cir. 1970); P.F. Collier \& Son Corp. v. FTC, 427 F.2d 261 (6th Cir. 1970); All-State Indus., Inc. v. FTC, 423 F.2d 423 (4th Cir.), cert. denied, 400 U.S. 828 (1970); Haskelite Mfg. Co: v. FTC, 127 F.2d 765 (7th Cir. 1942); Biochemic Research Foundation, 3 Trade Reg. Rep. ๆ 20,463 (FTC 1973); Procter \& Gamble Co., 79 F.T.C. 589 [1970-73 Transfer Binder] TradE REG. REP. I 19,774 (1971); Arlington Imports, Inc., 77 F.T.C. 1109 [1970-73 Transfer Binder] Trade REg. REP. If 19,322 (F.T.C. 1970).

12 Corrective advertising is the more recent and more controversial type of FTC disclosure remedy. Firestone Tire \& Rubber Co., 81 F.T.C. 398 [1970-73 Transfer Binder] TradE REG. REP. I 20,112, aff'd, 481 F.2d 246 (6th Cir. 1972); Campbell Soup Co., 77 F.T.C. 664 [1967-70 Transfer Binder] Trade Reg. REP. I 19,261 (1970). See generally Lemker, Souped Up Affirmative Disclosure Orders of the Federal Trade Commission, 4 U. Mich. J.L. REF. 180 (1970); Likoff, Consumer Protection, 1973/4 ANN. SuRvey AM. L. 701 (1974). 
certain information in order to counteract the effects of past deception. Neither method, however, has been utilized without a prior finding of "deception." 43 Since the remedy of disclosure has been examined only in the context of deceptive acts or practices, a general deference to the FTC's broad discretion in fashioning remedies is insufficient to sustain the disclosure requirements in proposed Rules II and III which are premised solely on unfairness. This section of the comment will discuss the issue of whether the nondisclosure of drug price information is deceptive, and whether disclosure remedies can be utilized absent a finding of deception.

1. Nondisclosure as Deception. In an early case dealing with the nondisclosure of retail product information, Alberty v. FTC, ${ }^{44}$ the respondent had advertised a drug product as effective in relieving lassitude arising from one particular cause-iron deficiency. The FTC declared this advertisement deceptive and ordered the respondent to disclose in all future advertisements the additional fact that lassitude was caused less frequently by iron deficiency than by other causes against which the product was ineffective. ${ }^{45}$ The court held that the FTC could not order this disclosure. The ambiguity here, however, is whether the court denied the order merely because the FTC failed to make a showing of deception; or more broadly, because no deception can possibly be shown where, as here, the advertisers "state accurately the limited benefits of their product [but fail merely] . . . to call attention to what their product will not do." 46 The latter interpretation would suggest that disclosure cannot be required where the absence of information is not deceptive, even if such information would be useful to consumers. As the court stated:

$[w] e$ think that the negative function of preventing falsity and the affirmative function of requiring or encouraging additional interesting and perhaps useful information which is not essential to prevent falsity, are two different functions. . . . Congress gave the Commission the full of the former but did not give it the latter. ${ }^{47}$

This language suggests that the FTC may not require disclosure of drug prices unless the nondisclosure of such prices involves a deception on the part of retail pharmacists-a deception which the FTC

\footnotetext{
${ }^{13}$ See Likoff, Consumer Protection, supra note 42, at 701.

" 182 F.2d 36 (D.C. Cir. 1950).

is Id. at 38-39.

"Id. at 39 .

${ }^{17} I d$.
} 
has not alleged. ${ }^{48}$ Alberty might be distinguishable, however, in that the court in that case was particularly concerned that granting the FTC broad authority to require self-derogatory disclosures by advertisers would have an adverse impact on the general marketing of products. The disclosure of drug price information, on the other hand, is not self-derogatory; and its impact on the marketing of drugs would, according to the FTC, be beneficial. ${ }^{49}$

Subsequent decisions have consistently affirmed FTC orders compelling affirmative disclosure of self-derogatory information in factual situations very similar to Alberty, attributing to Alberty only the narrow holding that no adequate showing of deception was made in that case (but that given such showing the FTC could compel the disclosure).$^{50}$ Although the current judicial trend is not clearly in favor of the "informative function"-which Alberty regarded as beyond FTC authority-the judicially acceptable definition of "deception" has been increasingly liberalized, and the FTC would not necessarily be unable to so characterize the nondisclosure of drug prices. It might be argued that nondisclosure "deceives" consumers into assuming that drug prices do not vary substantially from one pharmacy to another, and that consumers are thereby injured. Thus nondisclosure constitutes a "deceptive act or practice." The major deficiency in this argument is that the causal relationship between nondisclosure by pharmacists and consumer misconception is not entirely clear. On the other hand, even if pharmacists can only be held nominally responsible for the misconception, that may be sufficient, inasmuch as the courts have typically taken an exceedingly patronizing view of consumer mentality and the FTC's role in protecting against consumer errors. As the courts have repeatedly stated, the FTC was created for the protection of "the ignorant, the unthinking, and the credulous."

Although "deception" is seemingly a more improbable legal theory than "unfairness" for justifying the FTC's power to require disclosure of drug prices, it is not entirely without precedential support. These precedents ${ }^{52}$ suggest, at minimum, that retailers may be

s8 See note 10 supra (text of proposed rules).

19 StafF Report, supra note 4, at 2.

so See J.B. Williams Co. v. FTC, 381 F.2d 884 (6th Cir. 1967); Feil v. FTC, 285 F.2d 879 (9th Cir. 1960); Keele Hair \& Scalp Specialists, Inc. v. FTC, 275 F.2d 18 (5th Cir. 1960). Only one court, in Feil v. FTC, 285 F.2d 879 (9th Cir. 1960), has specifically disapproved Alberty's broad rejection of the "informative function" with respect to FTC remedies. $285 \mathrm{~F} .2 \mathrm{~d}$ at 900 01 .

${ }^{31}$ E.g., Nirsek Indus., Inc. v. FTC, 278 F.2d 337 (7th Cir. 1960); Harsam Distrib., Inc. v. FTC, 263 F.2d 396 (2d Cir. 1959); Florence Mfg. Co. v. J.C. Dowd, 178 F. 73 (2d Cir. 1910).

52 Cases cited note 51 supra. 
held responsible by the FTC for deceptive acts or practices even though the retailers are not wholly to blame for the consumers' misconception. This proposition augurs well for the FTC stance against retail pharmacists. Most of these cases, admittedly, also involve extant affirmative acts of disclosure and not merely, as in the case of pharmacists, "pure" failure to disclose. But this distinction is not always crucial. ${ }^{53}$

2. Disclosure as a Remedy for Unfairness. Although the characterization of the nondisclosure of drug prices as deceptive is possible, the more tenable characterization and the one being advanced by the FTC is as an "unfair act or practice." An unfairness rationale for mandatory disclosure would unquestionably be novel to the theory, but not to the apparent policy concern, to which the courts have heretofore subscribed in permitting the FTC to require disclosure of material facts about retail products. This policy concern is no less broad, or less flexible, than that stated by Judge Learned Hand in FTC v. Standard Education Society:" "[The Commission's] duty . . . is to discover and make explicit those unexpressed standards of fair dealing which the conscience of the community may progressively develop." 55 With respect to this underlying policy concern, unfairness and deception are sufficiently similar to warrant similar remedies.

The FTC has employed disclosure as a remedy through rulemaking in the past. ${ }^{56}$ Particularly relevant in this regard is the

ss The cases support the general proposition that nondisclosure of material facts may constitute deception even in the absence of affirmative disclosure, but do not specifically support the additional proposition that such nondisclosure constitutes deception even if the alleged deceiver is not wholly to blame, either morally or causally, for the deception. See, e.g., Bantam Books, Inc. v. FTC, 275 F.2d 680 (2d Cir. 1960); Mohawk Ref. Corp. v. FTC, 263 F.2d 818 (3d Cir. 1959); American Tack Co. v. FTC, 211 F.2d 239 (2d Cir. 1954) (per curiam); L. Heller \& Son, Inc. v. FTC, 191 F.2d 954 (7th Cir. 1951); Segal v. FTC, 142 F.2d 255 (2d Cir. 1944). See also Dorfman v. FTC, 144 F.2d 737 (8th Cir. 1944).

st 86 F.2d 692 (2d Cir. 1936), rev'd on other grounds, 302 U.S. 112 (1937).

ss Id. at 696.

st Promulgated trade regulation rules which have required affirmative disclosures are listed by title as follows, in reverse chronological order of effective date: Deceptive Advertising and Labeling as to Length of Extension Ladders, 16 C.F.R. $\$ 418$ (1970); Games of Chance in the Food Retailing and Gasoline Industries, 16 C.F.R. $\$ 419$ (1972); Failure to Disclose the Hazards of Inhaling Quick-Freeze Aerosol Spray Products Designed for the Frosting of Beverage Glasses, 16 C.F.R. $\$ 417$ (1969); Failure to Disclose that Skin Irritation May Result from Washing and Handling Glass Fiber Curtains and Drapery Fabrics, 16 C.F.R. $\& 413$ (1968); Deceptive Advertising and Labeling as to Size of Tablecloths and Related Products, 16 C.F.R. $\S 404$ (1965); Deceptive Advertising and Labeling of Previously Used Lubricating Oil, 16 C.F.R. $\S 406$ (1972); Misbranding and Deception as to Leather Content of Waist Beits, 16 C.F.R. $\$ 405$ (1972); Deception as to Nonprismatic and Partially Prismatic Instruments Being Prismatic Binoculars, 16 C.F.R. $\$ 402$ (1964); Advertising and Labeling of Sleeping Bags as to Size, 16 C.F.R. $\S 400$ (1972). 
FTC's Trade Regulation Rule Relating to the Care Labeling of Textile Products, ${ }^{57}$ which provides a substantial legal foundation for FTC authority to require disclosure of facts. The rule requires manufacturers and marketers of textile products to label their products with clear instructions for the maintenance of the product's utility and appearance. The rule is premised on the assumptions that lack of such information may result in impairment of the product's utility or appearance and, since consumers are not apprised of the necessary procedures for maintenance, they are precluded from choosing rationally among competing products. Thus this rule, like proposed Rules II and III, requires disclosure of material information about a retail product.

The Textile Labeling Rule is superficially distinguishable from the Drug Price Rules in two related respects. First, a concern behind the Textile Rule was that the products in question would, due to no fault of the purchaser, be impaired after purchase; the Drug Price Rules, in contrast, are not relevant to the continued quality of the product after purchase. Second, the Federal Register records on the Textile Rule indicate that consumers were being "misled and deceived" about what maintenance procedures were necessary. Therefore, the Textile Rule is distinguishable on the grounds that it was designed to remedy a situation where the consumer is uninformed at the time of purchase about an essential attribute of the product purchased, whereas in the prescription drug situation the consumer is not uninformed in this way. These distinctions do not suggest, however, that drug price nondisclosure is inherently less worthy of regulation. Rather, the Textile Rule and the Drug Price Rules can be characterized more broadly: both are concerned chiefly with helping the consumer to purchase rationally, and both are addressed to the danger that consumers may suffer an economic detriment due to the absence of information.

Substantially the same public interest rationale that underlies the Textile and Drug Price Rules has received express congressional sanction. Although congressional authority, based as it is on the commerce clause, is more extensive than FTC authority to proscribe "unfair acts or practices," various measures that Congress has adopted suggest that the mandatory disclosure requirement in Rules II and III is largely consistent with existing congressional policy. The Automobile Information Disclosure Act, ${ }^{58}$ for example,

${ }^{57} 34$ Fed. Reg. 17,776 (1969). See also The Posting of Research Ratings on Gasoline Dispensing Pumps, 34 Fed. Reg. 12,449 (1969).

5815 U.S.C. $\$ \S 1231-33$ (1970). 
provides that automobile manufacturers must affix price information to the windshield of all cars distributed by them in commerce. In United States $v$. Cummings, ${ }^{59}$ the only case in which that Act was challenged, ${ }^{80}$ the court expressly confirmed that the price disclosure requirement was a valid exercise of congressional power. Admittedly, two differences between this Act and the Drug Price Rules detract from the Act's precedential value. The requirement in the Automobile Act was imposed on manufacturers, not retailers as in the FTC rules. The pecuniary burden of disclosure would be considerably less serious for manufacturers and therefore a less significant factor to be considered by Congress. Also, the price-packing abuse among automobile dealers was found to be much more extensive than any alleged price-packing among retail pharmacists. This factor seemed to weigh quite heavily in the congressional reports. ${ }^{81}$

These distinctions should not obscure the more central fact that Congress has seen fit to require businesses to disclose facts in order to aid consumers, enhance competition, and deter consumer exploitation. Another significant example of this policy is the Truth in Lending Act, ${ }^{82}$ which requires disclosure of credit terms by crediting institutions and retail lenders "so that the consumer will be able to compare more readily the various credit terms available to him." Like the Automobile Act, the Lending Act is distinguishable from the FTC rules. First, Congress, in passing the Lending Act, was likely motivated in part by the particular unfairness of imposing a future obligation on consumers (i.e., the repayment of the credit borrowed) without making clear the conditions of that obligation. In contrast, the nondisclosure of drug prices imposes no such future obligation: consumers, in purchasing drugs, are completely aware of the transaction to which they are consenting. Second, Congress seems to have attributed the unavailability of credit terms not merely to the "inconvenience" of obtaining such information (as in the case of drug price information ${ }^{84}$ ), but rather to the inability of lay consumers to make sophisticated computations on the basis of the inadequate data furnished by the creditors or to the literal impossibility of computing rates on the basis of such limited data. Notwithstanding these distinctions, the Lending Act testifies to the legal soundness of the FTC disclosure remedy, and not merely be-

\footnotetext{
31 184 F. Supp. 18 (W.D. Pa. 1960).

so The challenge was solely on jurisdictional grounds.

"U.S. Code Cong. \& Admin. News, 85th Cong., 2d Sess. 2902 (1958).

$\because 215$ U.S.C. \& 1601 (1970).

(3) Id.

" Staff Report, supra note 4, at 16.
} 
cause the Act was, like the rules, designed to promote price comparison and protect the consumer. More notably, the Lending Act was specifically intended to remedy not only the deceptive disclosure of credit terms but also, like the FTC rules, "pure" nondisclosure without deception. ${ }^{65}$

\section{FTC Preemption of State Disclosure Laws}

\section{A. Displacement by Administrative Rules}

Even though the nondisclosure of prescription drug prices can likely be remedied, if unfair, by rules requiring disclosure, Rules II and III are not valid unless, in addition, the FTC has authority to preempt state laws that restrict such disclosure. The rules represent the FTC's first nationwide attempt to displace state law. ${ }^{66}$

Under the judicial doctrine of federal preemption, as founded on the supremacy clause, ${ }^{87}$ a valid federal law will displace any inconsistent state laws. The doctrine applies no less legitimately to valid administrative regulations than to statutes enacted by Congress, since "regulations promulgated under specific statutory au-

${ }^{65}$ See note 62 supra.

"A A proposed amendment to the Federal Trade Commission Act, which would have rendered all state restrictions on prescription drug price disclosure "unfair acts or practices," was introduced in the House of Representatives during the Ninety-second Congress, but not passed. H.R. 5938, 92d Cong., 1st Sess. (1971). See also H.R. 5736, 93d Cong., 1st Sess. (1973) (a later version of H.R. 5938, also unpassed).

Note further that state disclosure laws, particularly statutes as distinguished from state pharmacy board regulations, are currently being challenged on constitutional grounds. See cases cited note 38 supra. These challenges are typically based on the argument that the statutes constitute an improper exercise of the police power. See Comment, Regulation of Prescription Drug Discount Advertising, 24 WASH. \& LeE L. Rev. 299 (1967); 37 BrookLyn L. REV. 617 (1971). A more curious theory of unconstitutionality was upheld in Virginia Citizens Consumer Council, Inc. v. State Bd. of Pharmacy, 373 F. Supp. 683 (E.D. Va. 1974), prob. juris. noted, 420 U.S. 971 (1975), where a three-judge district court held that a Virginia statute violated plaintiffs-consumers' first amendment "right to receive" (inferred from that amendment's prohibition against abridgement of freedom of speech). The defendant was granted appeal to the Supreme Court, where decision is now pending. Contra, Valentine v. Chrestensen, 316 U.S. 52 (1942). For further discussion of first amendment challenges, see Comment, The Right to Receive and the Commercial Speech Doctrine: New Constitutional Considerations, 63 Gro. L.J. 775 (1975); Comment, The Constitutionality of a Statute Prohibiting Advertising of Prescription Drug Prices, 28 OKLA. L. Rev. 350 (1975).

State disclosure laws have previously undergone slight displacement by the Federal Price Commission. Under the Economic Stabilization Act of 1970, 12 U.S.C. $§ 1904$ (1970), the Commission promulgated regulations requiring retail pharmacists having total annual sales in excess of $\$ 200,000$ to post the base prices of the 40 best-selling drugs. 6 C.F.R. $\$ 300.5$ (1972), 36 Fed. Reg. 23974 (1971). The Commission has ruled that state laws prohibiting posting of the sort required by the federal regulations were unenforceable under the supremacy clause. Economic Controls, Stabilization Program Guideline, CCH II 537.25 (1973).

${ }^{87}$ U.S. Const. art. VI, cl. 2. 
thority [have, like statutes,] the force of law upon promulgation, and so long as they are confined within the limits of statutory delegation, their force will be recognized by the courts." the Supreme Court has provided substantial support for the proposition that legislative rules validly adopted by a federal agency can render inconsistent state laws unenforceable..$^{89}$

Thus the question of FTC authority to displace state law through proposed Rules $I I$ and III involves two additional issues: whether the rules are sufficiently inconsistent with state disclosure laws to compel displacement, and if so, whether FTC rules that purport to displace state law are within the FTC's statutory grant of power or are barred by the doctrine of Parker $v$. Brown.

\section{B. Inconsistency and Mechanical Repugnancy}

A broad test is generally invoked to determine the preemptive effect to be accorded a federal administrative regulation. In Florida Lime \& Avocado Growers v. Paul, the Supreme Court held that if an agency's enabling statute evinces no clear congressional intent to displace the state law in question, then displacement is permissible only if simultaneous compliance with both the federal regulation and the state law is "physically impossible." Ap Applying this socalled "mechanical repugnancy" standard, the Court in Florida Lime ruled that a federal marketing order, issued by the Depart-

united States v. Jones, 204 F.2d 745, 753 (7th Cir. 1953); accord, United States v. Mersky, 361 U.S. 431, 437-38 (1960); Doran v. United States, 304 F. Supp. 1162, 1169 (D.P.R. 1969); Stork v. United States, 278 F. Supp. 869, 875-76 (E.D. Wis. 1968); K. DAvis, ADMinIsTRATIVE LAW TrEatiSE $\$ 5.03$ (1958); see cases cited note 69 infra. The power of "legislative" rules to displace state law is not subverted by a determination that the agency's enabling statute would not preempt state laws by its own force (i.e., in the absence of such rules). Thus displacement by the FTC Rules is not at odds with Patterson Drug Co. v. Kingery, 305 F. Supp. 821 (W.D. Va. 1969), where a district court held that the Federal Trade Commission Act evinces no specific congressional design to preempt state regulation of prescription drug price disclosure, and no "actual conflict" necessitating such preemption.

" Free v. Bland, 369 U.S. 663 (1962); Public Utilities Comm'n v. United States, 355 U.S. 534 (1958); Leslie v. Arkansas, 352 U.S. 187 (1956). See also Head v. New Mexico Bd. of Examiners in Optometry, 374 U.S. 424 (1963).

The preemptive force of Trade Regulation Rules is not addressed in the Federal Trade Commission Improvement Act, and is largely ignored in the legislative history. The principal exception is a prepared statement before a House Subcommittee by a spokesman for the Consumer Bankers Association. Hearings on H.R. 20 and H.R. 5021 Before the Subcomm. on Commerce and Finance of the House Comm. on Interstate and Foreign Commerce, 93d Cong., 1st Sess., ser. 93-17, at 207 (1973) (statements of Walter W. Vaughn). There thus exists no substantial indication that Congress was specifically cognizant that the rules sanctioned by the Act could or should preempt state laws. The reports of both the House and Senate are silent in this respect.

773 U.S. 132, 143 (1962). 
ment of Agriculture pursuant to a statute, could not displace a California statute which excluded from California markets certain avocados which the federal order certified to be marketable. ${ }^{71}$

The FTC is technically correct in concluding that Florida Lime supports the preemptive power of Rules II and III, but for the wrong reason. The FTC argues that Rule $\Pi$ is mechanically repugnant to state disclosure laws because it is impossible for pharmacists to disclose prices and not take account of state laws, and at the same time obey state laws prohibiting disclosure. This application of the test mistakenly assumes that Rule II requires pharmacists to "disclose prices and not take account of state laws." "What the rule actually requires is that pharmacists either disclose prices or not take account of state laws. Thus the FTC ignores the possibility that a pharmacist could indeed comply with both Rule II and state law by simply refraining from disclosure without doing so in deference to state law or private restraints. Furthermore, even Rule III, requiring disclosure by certain specified methods regardless of the absence of restraints, would not satisfy the physical impossibility test when evaluated in conjunction with many state disclosure laws. This is because many states, while permitting disclosure by those methods which Rule III would require ${ }^{73}$ prohibit general media advertising; Rule III, in contrast, will not be formulated so as to require media advertising, for the FTC anticipates that such a requirement might lead to excessive commercialization. ${ }^{74}$ Therefore Rule III, and those state laws which prohibit media advertising while permitting other methods of disclosure, can be simultaneously satisfied if the pharmacist discloses prices by such methods yet refrains from media advertising.

The mechanical repugnancy test does not represent an obstacle to the preemptive power of the proposed rules. The Florida Lime Court, in announcing the test, was concerned with two essential points: (1) "whether both [the federal and the state] regulations

"The Court concluded that "physical impossibility" obtained only "if, for example, the federal orders forbade the picking and marketing of any avocado testing more than $7 \%$ oil, while the California test excluded from the state any avocado measuring less than $8 \%$ oil. . . ." Id.; cf. Double-Eagle Lubricants, Inc. v. Texas, 248 F. Supp. 515 (N.D. Tex.), appeal dismissed, 384 U.S. 434 (1966); Royal Oil Corp. v. FTC, 262 F.2d 741 (4th Cir. 1959). As used by the courts, physical impossibility is a slightly exaggerated term, because it presupposes that the would-be law abider, faced with mechanically repugnant laws, will continue in his present business capacity rather than abandon his business in order to avoid the conflict.

12 STAFF REPort, supra note 4, at 504.

${ }^{73}$ See note 5 supra.

"Staff Report, supra note 4, at 508. 
can be enforced without impairing the federal superintendence of the field" $;^{75}$ and (2) whether the state regulation "stands as an obstacle to the accomplishment and execution of the full purposes and objectives of Congress." "76 With respect to both of these concerns, displacement by the proposed FTC rules seems favored-in fact, inevitable-assuming the validity of the rules otherwise. Any pharmacist who discloses prices and is prosecuted under state law may thereupon invoke either rule as a defense. Since either rule will have required the pharmacist to disclose prices rather than heed state law, the state law will fall. The FTC rules, if valid otherwise, thus displace state law inherently, and any further question about their power to displace is illogical. Unlike the FTC rules, the federal regulations in Florida Lime did not inherently displace state laws.

\section{The Relevance of Parker v. Brown}

The second and more critical issue is whether the FTC has statutory authority to displace state law. The doctrine of Parker $v$. $B r o w n^{77}$ has been held to limit the scope of antitrust laws, including by implication the Federal Trade Commission Act, when directed against "state action."78 The doctrine poses a serious and in all likelihood insuperable obstacle to the preemptive power of the proposed FTC Drug Price Rules.

Parker involved an action by an individual raisin producer to enjoin the California Director of Agriculture and other state officials from instituting a raisin proration marketing program as required by a state statute. Plaintiff claimed that the state program obstructed competition and was invalid under the Sherman Act. The Court, in upholding the state program, held that the action taken to install the program was not within the scope of the Sherman Act. The elusive rationale for this decision rests mainly on two levels of generality. First and more specifically, the Court concluded, after reviewing the Act's legislative history, that the action of state officials cannot properly be regarded as a "contract, combination, or conspiracy," pursuant to the Sherman Act, because that phrase contemplates only "private persons, individual or corporate." Secondly, the Court stated that the Sherman Act was not intended to

75373 U.S. at 142.

7 Id. at 141, citing Hines v. Davidowitz, 312 U.S. 52, 67 (1941).

7317 U.S. 341 (1943).

78 "State action" as used in the context of Parker should not be confused with the meaning which this term has acquired in contexts such as the interpretation of the equal protection clause of the United States Constitution.

317 U.S. at 350 . 
"restrain a state or its officers or agents from activities directed by its legislature." seems merely to delimit the class of persons against whom an action based on the Sherman Act may be directed. In other words, the Court meant simply that state officials cannot be sued, as can private individuals, under the Sherman Act. Insofar as Rules II and III do not purport to authorize prosecution of state officials, the preemptive power of the rules remains intact under this interpretation.

By the broader interpretation, however, Parker has been understood to foreclose antitrust prosecution of many actions mandated by state law, regardless of whether such actions are undertaken by private individuals, as in the nondisclosure of drug prices, rather than by state officials. ${ }^{81}$ But this broader and, for the FTC, more threatening interpretation of Parker cannot stand unqualified, for the Court noted expressly that "a state does not give immunity to those who violate the Sherman Act by authorizing them to violate it." 82 The threshold question, left open by Parker, is what if any state-authorized private activities are sufficiently intrinsic to the state to render antitrust scrutiny of such activities an impermissible restraint on "state action." The answer to this question calls for an analysis of the applicability of the Parker doctrine to the Federal Trade Commission Act and an examination of what constitutes state action for purposes of the doctrine.

1. The Applicability of Parker v. Brown to the Federal Trade Commission Act. Although few courts have considered the question whether the Parker doctrine, which was established in the context of the Sherman Act, operates to immunize activities prosecuted under the Federal Trade Commission Act, the probable answer is affirmative both in principle and according to precedent. ${ }^{83}$

${ }^{80}$ Id. at $350-51$.

81 See generally Donnem, Federal Antitrust Law Versus Anticompetitive State Regulations, 39 A.B.A. ANTITRusT L.J. 950 (1970); Jacobs, State Regulation and the Federal Antitrust Laws, 25 CASE W. Res. L. REv. 221 (1975); Kirkpatrick, The State Action Antitrust Immunity Defense, 23 AM. U.L. REv. 527 (1974); Posner, The Proper Relationship Between State Regulation and the Federal Antitrust Laws, 49 N.Y.U.L. REv. 693 (1974); Simmons \& Fornaciari, State Regulation as an Antitrust Defense: An Analysis of the Parker v. Brown Doctrine, U. CIN. L. REv. 61 (1974); Slater, Antitrust and Government Action: A Formula for Narrowing Parker v. Brown, 69 Nw. U.L. Rev. 71 (1974); Note, Of Raisins and Mushrooms: Applying the Parker Exemption, 58 VA. L. REv. 1511 (1972).

${ }^{82} 317$ U.S. at 351.

${ }^{83}$ Also supporting this conclusion are the text and legislative history upon which the Parker Court ostensibly relied in concluding that the Sherman Act was not intended to "restrain a state . . . from activities directed by its legislature." Like the Sherman Act, the Federal Trade Commission Act (1) is addressed only to "persons, partnerships and 
In Asheville Tobacco Board of Trade, Inc. v. FTC, ${ }^{84}$ the relevant question was whether the allegedly anticompetitive regulations adopted by a local trade board were exempt from FTC prosecution under Parker. The case is noteworthy because the court assumed that the Parker doctrine applied to the Federal Trade Commission Act. ${ }^{85}$ This assumption was apparently shared by the Fourth Circuit in Goldfarb v. Virginia State Bar ${ }^{86}$ which concluded in dictum: "The Asheville case involved the Federal Trade Commission Act instead of the Sherman Act, the latter being the controlling statute in Parker ... [therefore] it appears that the [Parker] exemption can be applied regardless of the specific antitrust law involved." ${ }^{87}$ While this broad proposition, if true, indicates that the FTC cannot dismiss out of hand the applicability of Parker to Rules II and III, the more difficult question is the extent to which the Asheville court would have considered the FTC subject to Parker if the FTC's prosecution were premised, not upon a strictly "anticompetitive" theory analogous to the Sherman Act, but rather upon an "unfair act or practice" theory, as it is in proposed Rules II and III.

In Asheville, the question as phrased by the court was whether the trade board's regulations constituted "unfair methods of competition and unfair acts or practices . . . within the meaning of the Federal Trade Commission Act."'88 The court failed to distinguish between an "unfair method of competition" and an "unfair act or practice"; instead, it apparently merged the two, or more accurately subsumed the latter phrase within the former, such that "unfair act or practice" bore no autonomous meaning for the court.

corporations." $\S \S 203($ a)-(b), U.S. Code Cong. \& Admin. News, 93d Cong., 2d Sess. 2551 (1974); and (2) "gives no hint of a purpose to restrain state action in the Act's legislative history." 317 U.S. at 351.

Notwithstanding these indicia of legislative intent, the only pre-Parker court faced with a preemption situation approved preemption without apparent qualification. Chamber of Commerce of Minneapolis v. FTC, 13 F.2d 673 (8th Cir. 1926). Here the FTC had sought to prohibit certain allegedly anticompetitive practices compelled by rules adopted by a local Chamber of Commerce. The defendant Chamber defended on the grounds that the adoption of said rules was authorized by state statute. The court, though refusing to find the instant practices anticompetitive, stated in dicta that "Congress, in the Federal Trade Commission Act, has assumed to legislate concerning 'unfair methods of competition' . . . and if any action by, or any rule . . . of the Chamber has that effect it is certainly subject to the Act, no matter what the state has or has not authorized or permitted in that respect. Any action by the state legislature ... falls blunted if it strikes at this power which Congress vested . . . in the Commission." Id. at 684.

s 263 F.2d 502 (4th Cir. 1959).

${ }^{85}$ The court ultimately refused to apply Parker in this case, but only because the tobacco board's regulations were found not to be within the scope of state action.

s 497 F.2d 1 (4th Cir. 1974), rev'd on other grounds, 421 U.S. 773 (1975).

${ }^{87} \mathrm{Id}$. at 7 n. 15 .

s 263 F.2d at 505 . 
On the basis of this analysis, the argument could be advanced that the Asheville court was willing to subject the Federal Trade Commission Act to Parker only because the Act was being invoked against what the court correctly perceived to be a "merely" Sherman Act-type violation ("unfair method of competition") and that the nondisclosure of drug prices, as an "unfair act or practice," involves a greater social harm-widespread injury to consumers-than did the merely Sherman Act-type violation in Asheville. In other words, as a matter of public policy an "unfair act or practice" such as nondisclosure is less deserving of Parker immunity than an "unfair method of competition," because the former is more detrimental to society at large and less offset by state interests in preserving the act or practice.

The initial problem with this argument is that the Asheville court, which hinted at no such distinction, seems to stand for the general proposition that the FTC is not significantly different from the Sherman Act for Parker purposes. But more fundamentally, the argument is belied by the legislative history of the Wheeler-Lea Amendments. The Senate Report indicates that the term "unfair act or practice" was added primarily as a strategic means of retaining FTC jurisdiction over an act otherwise culpable as an "unfair method of competition." The Report stated:

Under the present Act, it has been intimated in court decisions that the Commission may lose jurisdiction of a case of deceptive or similar unfair acts. Under the proposed amendment, the Commission would have jurisdiction to stop the exploitation or deception of the public, even though the competitors of the respondent are themselves entitled to no protection because of their engaging in similar practices. ${ }^{80}$

This statement implies that the phrase "unfair act or practice" was not intended to proscribe conduct that was necessarily any more injurious to consumers or less worthy of state protection than "unfair methods of competition." 90

s. S. REP. No. 221, 75th Cong., 1st Sess. 3 (1937); 83 CoNG. REc. 3255 (1938) (remarks of Senator Wheeler); id. at 391-92 (1938) (remarks of Representative Lea).

90 The Senate Report has not, of course, constrained the courts to confine the definition of "unfair act or practice" to practices that are otherwise culpable as "unfair methods of competition" but for the fact that respondent's competitors are engaging in similar practices. See text at notes 16-21 supra. But what remains true about the judicial definition of "unfair act or practice" is its frequent overlap with that of "unfair method of competition"; and the social and economic consequences attaching to the practices comprised by each are not rigidly distinguishable. In this connection the FTC has conceded that the nondisclosure of prescription drug prices constitutes an "unfair method of competition" as well as an "unfair act or 
Another argument ${ }^{91}$ by which the FTC seeks to evade the implication of Asheville is even more basic, but no more persuasive, than the distinction between "unfair acts or practices" and "unfair methods of competition." The argument is simply that Asheville was wrong in applying Parker to the FTC Act at all, even if the grounds for prosecution in Asheville were limited to the "unfair method of competition" portion of the Act. This is because the phrase "unfair method of competition" embraces, and was intended to embrace, a broader range of conduct than the Sherman Act.

That the FTC Act is broader in scope than the Sherman Act is well established, ${ }^{92}$ but hardly in itself a compelling reason to insulate the FTC from Parker. The argument would be stronger if, at the least, the conduct proscribed by the FTC Act which is not also proscribed by the Sherman Act was somehow more deserving of prosecution or less worthy of state protection than conduct proscribed commonly by both; and, assuming this, that the nondisclosure of drug prices constituted conduct over which only the FTC has jurisdiction. The FTC has failed to demonstrate or claim either of these propositions. Both are doubtful, ${ }^{93}$ particularly the first. ${ }^{94}$

The weakness of the FTC argument that the Parker doctrine should not be applied to the FTC Act is also illustrated by the Supreme Court decision in Goldfarb $v$. Virginia State Bar, ${ }^{95}$ which involved the Sherman Act. Here the Court apparently felt no compunction about applying Parker $^{98}$ to an antitrust activity which was scarcely less injurious to consumers or otherwise less deserving of prosecution than the nondisclosure of prescription drug prices. The activity in question was the implementation of a minimum fee

practice." STAFF REPORT, supra note 4, at $320 \mathrm{~g}$. "So as to avoid any collateral problems associated with conducting a rulemaking proceeding to address an unfair method of competition, [the FTC] Staff recommends proceeding against the offenses only as "unfair acts or practices." Id. This apparent attempt to circumvent Parker by manipulating legal nomenclature is not bound to succeed so long as it rests on a distinction which makes no difference. Compare Rosten v. FTC, 263 F.2d 620 (2d Cir. 1959) (unfair act or practice), with Lichtenstein v. FTC, 194 F.2d 607 (9th Cir. 1952) (unfair act or practice), and Lane v. FTC, 130 F.2d 48 (9th Cir. 1942) (unfair methods of competition and unfair and deceptive acts and practices), and Carter Carburetor Corp. v. FTC, 112 F.2d 722 (8th Cir. 1940) (unfair method of competition), and National Candy Co. v. FTC, 104 F.2d 999 (7th Cir. 1939) (unfair method of competition).

"See Staff Report, supra note 4, at 518.

22 FTC v. Cement Institute, 333 U.S. 683 (1948); FTC v. R.F. Keppel \& Bros., 291 U.S. 304 (1934); FTC v. Gratz, 253 U.S. 421 (1920).

"s As evidence of the unreliability of the second proposition, see note 19 supra.

"FTC v. Cement Institute, 333 U.S. 683, 694 (1948).

ss 421 U.S. 773 (1975).

" As in Asheville, the Court declined to grant the Parker exemption, but on grounds unrelated to the type or quantum of injury caused by the unlawful activity. 
schedule for attorneys by state and county bar associations. The Court was not oblivious to the injurious impact of this activity on consumers; in fact, it was acutely aware of the injury because Goldfarb was a class action in which consumers were represented. As the Court noted, "[p]etitioners clearly proved that the fee schedule . . . 'deprive[d] purchasers and consumers of the advantages which they derive from competition. ${ }^{97}$. . . [1]n terms of . . . harming consumers like petitioners the price-fixing activities found here are unusually damaging."98

2. The Exemption of State-Authorized Nondisclosure. Since the Federal Trade Commission Act is vulnerable to the Parker doctrine, the question remains whether the state-authorized nondisclosure of prescription drug prices is exempt as "state action" and therefore irreconcilable with FTC displacement of state disclosure laws: The Goldfarb case ${ }^{99}$ bears heavily on this question. The Goldfarb Court stated broadly that the proper inquiry for determining if an activity is exempt as state action is "whether the activity is required by the state acting as sovereign." 100 It held that neither

97421 U.S. at 785.

98 Id. at 782 .

9 Goldfarb is the only recent Supreme Court application of Parker. See Continental Ore Co. v. Union Carbide \& Carbon Corp., 370 U.S. 690 (1962); Schwegmann Bros. v. Calvert Distillers Corp., 341 U.S. 384 (1951), discussed at note 104 infra.

${ }_{100} 421$ U.S. at 790. Prompted by the elaborate analysis of the "state action" exemption in Hecht v. Pro-Football, Inc., 444 F.2d 931 (D.C. Cir. 1971), cert. denied, 404 U.S. 1047 (1972) (permitting antitrust action against District of Columbia governmental authority acting under federal act and indicating in dictum that result would be the same for state governmental authority acting under state law), much of the recent commentary on Parker $v$. Brown has sought to prescribe a stricter test for the exemption than that of merely "whether the activity is required by the state acting as sovereign." See, e.g., Baker v. Mayor \& City Council of Baltimore, 1967 Trade CAs. 72,004 (Baltimore City, Md., Cir. Ct. 1967), remanded without affirmance or reversal sub nom. A \& H Transp., Inc. v. Mayor \& City Council of Baltimore, 249 Md. 518, 240 A.2d 601 (1968) (probably the only decided case which apparently employed the stricter test); authorities cited note 81 supra; Note, Parker v. Brown: A Preemption Analysis, 84 Yale L.J. 1164 (1975). The essence of this test, in all its variations, is that the state action must be "consistent" with some auxiliary antitrust policy (or perhaps any federal law, antitrust or not) in order to obtain the Parker exemption. "Where the various goals of the federal antitrust laws cannot be simultaneously achieved, so that a choice among them is necessary, the decision by a state to effectuate one of the recognized federal policies should not be considered inconsistent with paramount federal law." Id. at 1171. Thus, as the most prominent example, a private natural monopoly under active state superintendence might be said to ensure allocative efficiency and adequate profitability. Business Aids, Inc. v. Chesapeake \& Potomac Telephone Co., 480 F.2d 754 (4th Cir. 1973); Gas Light Co. v. Georgia Power Co., 440 F.2d 1135 (5th Cir. 1971); Washington Gas Light Co. v. Virginia Elec. \& Power Co., 438 F.2d 248 (4th Cir. 1971); Alabama Power Co. v. Alabama Elec. Cooperative, Inc., 394 F.2d 672 (5th Cir. 1968); Allstate Ins. Co. v. Lanier, 361 F.2d 870 (4th Cir. 1966). Contra, Jackson v. Metropolitan Edison Co., 419 U.S. 345 (1974). See generally Hale \& Hale, The Otter Tail Power Case: Regulation by Commission or Antitrust Laws, 1973 SuP. CT. REv. 99. The test frequently derives its preliminary justification 
the state nor the county bar association was exempt under Parker, upon finding that neither had been required by state law to issue fee schedules. ${ }^{101}$ By strong implication, ${ }^{102}$ however, the Court would have granted a state action exemption upon such a showing not only to the state bar (a state agency) but also to the bar association, which the Court recognized to be a private non-governmental organization. ${ }^{103}$ The Court seemed amenable to extending Parker

by reference to the rather inconspicuous acknowledgement in Parker that the state action in that case was consistent with the Agricultural Adjustment Act. 317 U.S. at 352-59. But see Handler, Twenty-Fourth Annual Antitrust Review, 72 Colum. L. Rev. 1 (1972); Pogue, The Rationale of Exemptions from Antitrust, 19 A.B.A. ANTTTRUST Section 313, 324 (1961). Even if plausible on more fundamental federalism grounds, the test would not undermine the status of state-authorized nondisclosure as a state action inasmuch as nondisclosure can in some sense be viewed as a means of preserving small competitors. Interview with Fred E. Schwartz, Executive Director of the Illinois Pharmaceutical Ass'n, Jan. 8, 1976. Reviewing courts are likely to be sensitive to this antitrust policy because the Federal Trade Commission Improvement Act specifically provides that any promulgated Trade Regulation Rule must be accompanied by a statement taking into account the impact of the rule on small businesses. U.S. Code, Cong. \& Admin. News, 93d Cong., 2d Sess. 2534 (1974). See generally Bork, Bowman, Blake \& Jones, Goals of Antitrust-A Dialogue on Policy, 65 Colum. L. Rev. 363 (1965).

The most radical version of the stricter test for applying Parker hinges precariously on the fact that the Agricultural Adjustment Act provided that "[t]he making of any . . . [approved marketing] agreement shall not be held to be in violation of any of the antitrust laws of the United States" (7 U.S.C. § 608(b) (1970)); accordingly, Parker should be limited to state actions protected by an express antitrust exception included in a federal law. Jacobs, State Regulation and the Federal Antitrust Laws, 25 CASE W. Res. L. REv. 221, 247 (1975). The Parker Court neither relied on nor even mentioned the foregoing exception.

The cogent objection to the judicially evolved Parker doctrine is not that it simply contradicts the two-tier federal system by denying federal supremacy over state law-even the staunchest proponents of federal supremacy concede that states enjoy some discrete regulatory power over activities within the state, and Parker itself emphasized that an unexpressed intent to displace state regulations is not to be lightly attributed to Congress. 317 U.S. 341, 351 (1943). Rather, the objection is that the doctrine creates an anomalous situation by exempting from antitrust prosecution activities which, if privately arranged, would be subject to prosecution but for the mere fact of sufficient state participation. This anomaly is said to be satisfactorily reconciled by the limiting principle, as yet unadopted by the courts, that Parker should apply only when the state authorization of the private activity in question can be said to rest on a policy which comports with some antitrust goal and which therefore is not to be second-guessed by the judiciary.

The limiting principle merely limits arbitrarily rather than resolves the ostensible anomaly which Parker creates, for activities which retain Parker immunity under the limiting principle might be just as subject to prosecution, if privately arranged, as those activities which do not. To draw a line between antitrust consistency and inconsistency is to imply that state legislatures are entitled to more respect when authorizing an unlawful private activity which exhibits such consistency, as compared with an unlawful private activity which does not. The legislative wisdom of authorizing an otherwise unlawful activity does not necessarily bear any relation to the question of antitrust consistency or inconsistency.

101421 U.S. at 790.

102 Id. at 788.

103 Id. at 790 . 
immunity to private parties "compelled by the direction of the State," 104 and in this regard it hastened to reaffirm its respect for "the authority of the State to regulate its professions." 105

Applying the Goldfarb standard for state action to the nondisclosure of prescription drug prices yields a finding of state action in most, but not necessarily all instances of nondisclosure induced by state law. When the state law involved is statutory, as it was in Parker, the Goldfarb standard is plainly satisfied; ${ }^{106}$ but when the law involved is merely a state pharmacy board regulation, then the presence of state action is less pronounced. Without exception, no pharmacy board regulation that restricts price disclosure is specifically authorized by a state legislature. Rather, the legislative grant of power is drafted broadly to permit such regulations "as may be necessary for the protection of the public" or "necessary and expedient for the practice of pharmacy." 107 Therefore, nondisclosure induced by pharmacy board regulations cannot be said to have been directly compelled by the legislative command of the state.

Since a legislature can delegate authority broadly without spe-

108 "In Parker v. Brown [citation], the Court held that an anticompetitive marketing program which 'derived its authority and efficacy from the legislative command of the state' was not a violation of the Sherman Act because the Act was intended to regulate private practices and not prohibit a State from imposing a restraint as an act of government." 421 U.S. at 788. "It is not enough that, as the County Bar puts it, [the County Bar's] anticompetitive conduct [was] 'prompted' by state action; rather, anticompetitive activities must be compelled by direction of the State . . . "Id. at 791; cf. Schwegmann Bros. v. Calvert Distillers Corp., 341 U.S. 384 (1951), which is not fundamentally inconsistent with the forthright Goldfarb statements. Here the state of Louisiana required that all liquor retailers having knowledge of a minimum price agreement between the liquor distributor and any one retailer not sell liquor at a price less than the minimum price established by that agreement. The Court, in refusing to enforce the state law, stated that "when a state compels retailers to follow a parallel price policy, it demands private conduct which the Sherman Act forbids. See Parker v. Brown, 317 U.S. 341, 350." 341 U.S. at 389. The FTC has underscored this statement to support the blanket proposition that Parker does not exempt from antitrust prosecution private retailers, such as retail pharmacists, whose conduct is compelled by state law. STAFF REPORT, supra note 4, at 535. But the problem with this argument is that the Schwegmann decision rested on a specific determination that Congress, in the Miller-Tydings Act, which authorized state "price-fixing" laws otherwise, had "meticulously omitted" approval of the price-fixing scheme at bar. 341 U.S. at 388. Thus the Court was confronted with what it understood to be a specific congressional refusal to authorize the private conduct which the state law sought to compel. It did not indicate that where, as in the case of drug price nondisclosure, no direct congressional disapproval of state laws compelling the private conduct is evident, the Parker exemption cannot obtain. See Parker v. Brown, 317 U.S. at 350 .

105421 U.S. at 793.

108 Id. at 788.

107 See, e.g., ME. Rev. Stat. ANn. § 2851(1) (1965); Miss. Code AnN. § 73-21-13 (1973); N.Y. Consol. Laws ANn. § 6804(a) (McKinney 1972); R.I. Gen. Laws $§ 5-19-6$ (Supp. 1974). 
cific guidelines, ${ }^{108}$ the lack of a direct legislative command with respect to nondisclosure of drug prices is not dispositive. Thus, the Goldfarb Court pursued the question of state action even after determining that no statute had compelled the respondents' activities directly; it specifically asked if the Virginia Supreme Court, in its capacity as "agency" of the state by virtue of broad legislative delegation, had mandated the fee schedules. This question presumably would not have been asked unless an affirmative answer were germane to its determination of state action. ${ }^{109}$ But the Court's approval of delegation for Parker purposes is not dispositive of the nondisclosure issue. The more telling question is whether the Goldfarb Court would have respected the directive of a state pharmacy board regulation in the same manner that it was willing to respect a directive by the Virginia Supreme Court. Both "agencies," it is true, had the power to compel private activity pursuant to broad legislative delegation. But the important distinction is that a state pharmacy board is composed primarily of independent retail pharmacists ${ }^{110}$ whose motives for promulgating anti-disclosure regulations are considerably more susceptible to self-interest. The inference arises that such regulations may be the result, not of state action, but of "individual action masquerading as state action"111 and thus are not at the direction of the state "acting as a sovereign." 112 The Goldfarb Court was aware of this possibility, and noted that "[t]he fact that the State Bar is a state agency for some limited purposes does not create an antitrust shield that allows it to foster anticompetitive practices for the benefit of its members." 113 In Goldfarb, however, the "masquerading" state agency was itself the subject of liability, whereas in the state pharmacy board situation, liability would attach only to innocent pharmacists complying with the board's ostensibly valid regulations. Goldfarb ultimately provides little clear indication of how the Court would decide under such circumstances.

3. Status of Individual Action Under State-Authorized Nondisclosure. Once it has been determined that the Parker doctrine prevents the FTC from displacing state statutory nondisclo-

los K. Davis, Administrative Law Text $\$ 2.05$ (1972),

103 421 U.S. at 790.

11' State pharmacy statutes frequently provide for the appointment of state trade association members to the state board. See, e.g., IOWA CODE ANN. $\$ 147.20$ (1972); KanSAS STAT. Ann. § 74-1605 (1972). See also F. Fletcher, Market Restraints in the Retail Drug INDUSTRY 45-49 (1967).

in Asheville Tobacco Bd. of Trade, Inc. v. FTC, 263 F.2d 502, 509 (4th Cir. 1959).

112421 U.S. at 791.

113 Id. 
sure rules, the status of individuals and private organizations must be determined. Given a valid state law prohibiting disclosure, it would be both illogical and unjust to allow the FTC to prosecute an individual for following the law; however, it is not clear whether the prosecution should be barred with respect to the rules of a private pharmaceutical association.

In California ex rel. Christensen v. FTC, ${ }^{114}$ a district court granted the State of California a preliminary injunction to prevent the FTC from proceeding against the California Milk Producers Board (a state agency) and an advertising agency (a private corporation) for the alleged dissemination of deceptive advertisements. Citing Parker, the court stated:

There is a substantial probability that: (1) there is not jurisdiction in the Federal Trade Commission to proceed against the State of California, its instrumentalities, its agencies, or its officers in their official capacities [citation omitted]; and (2) the FTC may not avoid this fact by seeking to proceed instead against a private corporation. . . aiding the State in carrying out the conduct in question. ${ }^{115}$

If the permanent injunction and declaratory judgment sought in this case are granted specifically with reference to protection of the private corporation, the Christensen case promises to go further than any other in applying the Parker doctrine to the FTC. ${ }^{116}$

What is left unclear by the Christensen court is the extent to which private corporations are to be protected. If, as the court suggested, Parker should immunize all private parties who can be said to be "aiding" the state, there seems to be little reason to conclude that "aiding" the state is limited to include only those private parties "employed" by the state. 117 The Parker exemption as applied

III 5 Trade REg. ReP. (1974-2 Trade Cas.) I 75,328 (N.D. Cal. Oct. 29, 1974).

115 Id. at 98,039 .

"18 The nature of the FTC's formal complaint in Christensen was not disclosed, but likely included, as do most FTC complaints, both the "unfair method of competition" and the "unfair or deceptive act or practice" ascriptions.

The formal nature of the complaint should not be relevant to the applicability of Christensen to the FTC Rules; Christensen would be no less significant precedentially, therefore, if the complaint in that case were not grounded, like the Rules, on a strict "unfair act or practice" theory. This may be discerned from the fact that the court's apparent rationale for extending Parker) to the FTC Act was unrelated to any one specific form of complaint. Rather, the court addressed itself to the Act as a whole: "[N]either the FTC Act nor its legislative history indicates that states, state agencies, state instrumentalities, or state officers in their official capacities were intended by Congress to be included within the terms 'persons, partnerships, or corporations.'" 5 Trade REg. REP. (1974-2 Trade Cas.) If 75,328, at 98,039 (N.D. Cal. Oct. 29, 1974).

17 The only policy consideration which distinguishes this narrow construction is the undesirability of discouraging private contractors from entering into government contracts for 
in Christensen would seem, like Goldfarb, to include pharmacists acting under compulsion of state law in violation of Rules II and III, at least when the state law is statutory. Furthermore, "aiding" the state might also be construed even more broadly to include any private parties who are furthering specific ends of the state with its approval. By this construction, Christensen would immunize not only pharmacists compelled by valid state law to violate Rules II or III, but also private pharmaceutical associations that violate Rule I by seeking to deter pharmacists from disclosing. ${ }^{118}$

A third possible construction of Christensen is that Parker immunizes any private party whose prosecution by the FTC is regarded by the reviewing court as a merely circuitous attempt by the FTC to reach the state itself. This broad construction seems justified by the desirability of discouraging the FTC from seeking to aggrandize its jurisdiction by prosecuting states indirectly. This policy is a fortiori when, as in the drug price disclosure situation, the private activity involves no autonomous culpability; that is, whereas the advertising agency in Christensen would still be guilty of the alleged deception had its actions not been at the behest of the state milk producers board, a retail pharmacist whose failure to disclose was not at the behest of state law would not be guilty of an unfair act or practice, unless of course some extralegal restraint were involved.

The uncertain scope of Christensen is only partly elucidated by E.W. Wiggens Airways, Inc. v. Massachusetts Port Authority, ${ }^{119}$ which the Christensen court cited to support its extension of Parker to private parties. In Wiggens, the defendant port authority, a state agency, entered into an allegedly anticompetitive leasing agreement with a private corporation whereby the latter would function as the exclusive fixed base operator at Logan Airport. Following a typical state action inquiry, the court initially held that the port authority, in entering into the agreement, was acting pursuant to legislative mandate and was therefore exempt from antitrust prosecution under Parker. More significantly, the court then held that the private corporation was also exempt, stating that "[i]f, as we have found, the Authority's conduct was lawful here it

fear that, if immunity were extended only to government agencies and not to their contractors, agencies would be encouraged to disregard FTC law in designing assignments for contractors, thus exposing the contractors themselves to prosecution. But this policy, while plausible, was evidently not considered by the Christensen court and, even if considered, would not be dispositive.

"Is Private pharmaceutical associations, however, could not be said to have "aided" the state except where the state has a disclosure statute.

11 362 F.2d 52 (1st Cir.), cert. denied, 385 U.S. 947 (1966). 
would be an unreasonable restriction on its freedom to hold that [the private defendant] acted illegally in having aided it." 120 The court thus suggested that private parties can be regarded as "aiding" a state, and are therefore exempt from prosecution, when such prosecution would constitute an "unreasonable restriction" of the state's "freedom" to act pursuant to a legislative mandate.

This holding, like that in Christensen, tolerates the extension of Parker to nondisclosing pharmacists acting under compulsion of state law, in that FTC prosecution would operate as an obvious restriction on the state's freedom to enforce its disclosure laws. The additional term "reasonable" does not seem to undermine this conclusion, assuming (as did the Wiggens court) the validity of the state law in question. In Wiggens, of course, as in Christensen, the relationship of the private party to the state, unlike that of retail pharmacists, was contractual. But this fact seemed merely incidental, as it did in Christensen, for the court's emphasis was on the fact of imposition on the prerogatives of the state. It can hardly be suggested that the imposition in Wiggens was greater than it would be if disclosure laws were involved: a state's freedom to execute a law authorizing a port authority to "operate and manage"121 a particular airport is presumably no less deserving of preservation than its freedom to enforce a law prohibiting drug price disclosure. In fact, the former is a weaker case, at least when the disclosure law involved is a statute rather than a pharmacy board regulation, because the statute in Wiggens did not specifically authorize any sort of leasing agreement or fixed base operation, whereas disclosure statutes manifestly authorize the prosecution of pharmacists for engaging in specified disclosure activity. ${ }^{122}$ To the extent, then, that Wiggens may be taken to circumscribe the Christensen rationale, Christensen seems to preclude FTC displacement through proposed Rules II and III. ${ }^{123}$

\section{ConcLusion}

The proposed FTC regulation of prescription drug price disclosure by retail pharmacists is legally suspect and not likely to withstand judicial review unimpeached. The Parker doctrine, although traditionally invoked in the Sherman Act context, will almost cer-

$120 I d$. at 56.

121 Id. at 55.

122 See note 5 supra.

123 Rule I, however, seems to remain intact, in that a state's freedom to enforce disclosure laws would not be "unreasonably restricted" by FTC prosecution of private pharmaceutical associations as mandated by that Rule. 
tainly invalidate Rules II and III to the extent that they purport to displace state disclosure statutes and, possibly, pharmacy board regulations. The mandatory disclosure provisions contained in Rules II and III strain the theory of deception upon which established FTC disclosure remedies are typically based, but deserve serious judicial attention as a remedy against unfairness, apart from deception. Given a preliminary finding that nondisclosure is unfair, therefore, the FTC should be able to compel disclosure, pursuant to Rule III, in those states without disclosure laws and prohibit private restraints pursuant to Rule I and deference thereto pursuant to Rule II. The theory of unfairness, conceptually amorphous and largely unutilized in the past, could serve not only as the rationale for increasing consumer access to prescription drug price information but as a potent means of establishing the FTC-with its healthy budget, professionalized staff, and relative unsusceptibility to privately vested commercial influences-as a genuinely national instrument of consumer protection.

Ronald B. Shwartz 